\title{
Neoliberalism as Entrepreneurial Governmentality: Contradictions and Dissonance within Contemporary English Housing Associations.
}

\section{Keith Jacobs \\ Tony Manzi}

\begin{abstract}
This paper has two aims: to provide a critical commentary on the value of neoliberalism in explaining contemporary housing policy and to critically examine recent practices that have been shaped by ideas most commonly associated with neoliberalism. It begins by distinguishing different interpretative variants of neoliberalism and some of the criticisms regarding its explanatory capability. Taking the example of housing associations in England, the paper makes use of Dardot and Laval's (2013) notion of 'entrepreneurial governmentality' to interpret how contemporary welfare professionals attempt to reconcile the competing tensions of individualism and egalitarianism in practice. Amongst the arguments put forward is that the extension of commercialism, commodification and competition has generated new fissures and dissonance within the sector. The conclusion suggests that contemporary variants of neoliberalism are best understood as a rationality that establishes entrepreneurial governmentality across sectors of government, the economy and social life.
\end{abstract}

KEYWORDS: Neoliberalism, Entrepreneurialism, Housing Associations, England. 


\section{Neoliberalism as entrepreneurial governmentality: contradictions and dissonance within contemporary English housing associations.}

\section{Introduction: variants of neoliberalism}

The impetus for writing this paper stems from our observation that academic debates surrounding neoliberalism (NL) are worthy of closer consideration because they inform not only the topics that housing researchers decide to focus on but also the methods chosen for exploring these topics. Moreover, whilst NL remains the predominant concept within the social sciences for explaining contemporary politics (including housing), scholars are divided as to what constitutes neoliberalism. Some see it as an example of a more pernicious form of capitalism (Duménil and Levy, 2004), a combination of politically inspired projects (Peck 2013), a set of shared values (Hilgers, 2010 and Holbrow, 2015) whilst others question the usefulness of the concept itself (Boas and Gans-Morse, 2009). Our aim is to provide a commentary on these debates in order to consider the utility of neoliberalism for understanding developments in contemporary housing policy. Though mainly based on a reading of academic perspectives on neoliberalism, the paper utilises interviews from a study of English housing associations conducted by one of the authors in 2016 and 2017. The paper is divided into four sections. Section one (the introduction), identifies four influential (albeit overlapping) variants of neoliberal thought. In the second section, we outline some of the major criticisms that have been levelled against the concept of neoliberalism. In providing a discussion of English housing associations, section three sets out an institutional and discursive framework to establish how this rationality affects the governance, values and practices of the sector. In section four, (the conclusion), we consider the wider application of these ideas and put forward some suggestions for critically orientated housing research.

Within the social science disciplines, neoliberalism is used to explain developments not only in housing policy but also a wide range of areas of politics and social life, including public and private institutions, economics, international relations and individual behaviour. Hodkinson (2011) provides a useful summary by differentiating four main interpretative variants. The first variant includes accounts that see NL ideology as a hegemonic project that can be sourced to the influence of policy thinktanks inspired by Hayek (1944) and Friedman (1962), a response to the economic and social upheavals that were a feature of the politics of the 1970s and a disavowal of Keynesian demand-side fiscal policies. According to this account, NL ideology operates as a 'shock doctrine' (Klein, 2007) following systemic crises and political instability that are intrinsic features of economic globalisation. NL is therefore described as being in a 'mutually constitutive relationship' with crisis (Peck, Theodore and Brenner, 2009, p. 95) and as involving 'more or less decisive passiverevolutionary interventions... based on variable configurations of coercion-consent' (Davies, 2011, p.110). As Peck and Tickell (2002) maintain these processes lead to forms of 'fast policy transfer' (pp.397-8), helping to explain their global nature. Within this variant, neoliberal ideology can be categorised as a 'thought collective', referring to a group of individuals exchanging ideas within a common intellectual framework 
(Mirowski and Plehwe, 2009). As Dean (2014) writes 'neoliberalism gains its coherence less as a doctrine, programme or rationality, more as a movement' (p.151). Its strength therefore emanates from opposing Keynesianism demand management and social welfare policies, which it is argued ultimately leads to forms of totalitarian rule.

The second variant can be labelled a political economy interpretation, wherein scholars argue that NL ideology is characterised by a suite of economic proposals designed to assist market-based growth. A broad and comprehensive political economy interpretation has been set out by David Harvey (2005). He writes:

\begin{abstract}
Neoliberalism... proposes that human well-being can best be advanced by liberating individual entrepreneurial freedoms and skills within an institutional framework characterized by strong private property rights, free markets and free trade. The role of the state is to create and preserve an institutional framework appropriate to such practices... State interventions in markets (once created) must be kept to a bare minimum because, according to the theory, the state cannot possibly possess enough information to second-guess market signals (prices) and because powerful interest groups will inevitably distort and bias state interventions (particularly in democracies) for their own benefit (Harvey, 2005, p.2).
\end{abstract}

Harvey casts neoliberalism as a set of proposals about the role of the state and the capacity of individuals to advance their interests. In this respect, Harvey's political economy account accords with other public policy scholars; for example, writers such as Self (2000, p.159) saw neoliberal ideology as comprising economic (prioritising markets), social (highlighting individualism) and political (emphasising the limited role of the state) intentions.

Since the 2008 global financial crisis (GFC), political economy explanations have been influential in tracing the significance of neoliberalism on economic priorities by showing how a banking crisis (caused by reckless lending and investment practices) was reframed as a fiscal crisis of the state (caused by profligate welfare spending) (see Blyth 2013). Crouch (2008) uses the term 'privatised Keynesianism' to illustrate how governments encouraged individuals and households (rather than governments) to incur debt to maintain the economy; an analysis shared by Lazzarato (2012). Peck and Tickell's (2002) analysis of the 'roll out' (enforcing competitiveness through bureaucratic institutions and 'para-state' forms) and 'roll back' (through privatisation and deregulation) variants of government policymaking provide an exemplar of this interpretation. According to Peck and Tickell, NL is used to justify both a contraction and extension of state forms thereby highlighting the paradoxical nature of the political project, by pursuing an 'economic critique employed to legitimate, empower and expand the state' (Davies, 2014, p. x).

Political economy interpretations provide a well-established component of contemporary housing research (see Glynn 2009; Slater 2012; Hodkinson, Watt and Mooney 2013; Watt 2016; Madden and Marcuse 2016). Scholars writing in this field link the success of interest groups to their capacity to not only utilise but also to advance neoliberal ideologies. Groupings, such as banks and finance institutions have thus successfully determined government rationalities to the extent that state 
agencies will routinely denigrate alternative (collectivist) ideologies from gaining traction. The increasingly prevalent literature on the 'financialization' of housing (see for example Aalbers 2016; Fields, 2017; Forrest and Hirayama, 2015) illustrates the dominance of these political economy analyses. In the setting of England, Watt and Minton (2016, p. 204) assert 'housing has been subject to prolonged neoliberal reforms under the twin lodestars of 'privatisation' by Conservative and coalition governments and "modernisation" by New Labour'. Watt and Minton have in mind policies such as the 'right to buy' legislation, incentives for investor landlords and first-time buyers, deregulation of the planning process and the transfer of housing stock from local authorities to housing associations.

Accounts depicting neoliberalism as an instrument to promote a new state form constitute a third variant in which government agencies are established to cement marketization as a mode of practice. According to Jessop (2007), as a distinctive feature of late capitalism, neoliberalism can be viewed as 'inexorably allengulfing....subjecting to the same imperatives health care no less than commerce, education no less then agriculture, art no less than manufacturing industry' (Jessop, 2007, p.82). Neoliberalism therefore establishes an inescapable logic, determining relationships, behaviours and social practices (see for example Swyngedouw, 2005).

The above explanations all share an emphasis on the economic rationality of neoliberalism. In contrast, scholarship within the fourth variant construes neoliberalism as an explicitly political rationality or mode of governmentality. Much of the research, is influenced by Foucault's (2008) account of power as a network of relations and crucially the reach of governmentality includes the individual, who is reconstituted as a rational entrepreneurial actor. For writers such Davies (2014), neoliberalism establishes competition as the basic normative principle of society and competitiveness as the ultimate individual and collective virtue, extended across all spheres, through the 'pursuit of the disenchantment of politics by economics' (p.4). Competition thus exerts a moral force; with those unsuccessful seen as less deserving owing to their lack of competitiveness. In a similar vein, Dardot and Laval (2013) see government as comprising a set of activities that demand subjects to be compliant with rules, norms and practices. Governmentality inspired analysis has become increasingly influential in revealing the ways that subjects are regulated and how informal rules become institutionalised (Bevir, 2012). Often focusing on the importance of 'soft power' or 'government at a distance', with individual behaviour as a key focus for policy intervention research in this variant identifies a shift from disciplinary power to self-regulation, 'bio-power' or 'ethopolitics' (see also Rose, 2001; Flint, 2010; McKee, 2009). These accounts claim that ideologically inspired proposals succeed because they are generative of the forms of knowledge from which policy is enacted. So, for example, calculative rationalities underpin the proliferation of data metrics and quantification in work settings and determine the kinds of practices to be adopted.

As we explain below, a governmentality approach is well placed to account for neoliberal practices. Thus, rather than tracing ideology as if it operated in accordance to immutable logics, attention is paid instead to actually existing neoliberalism. Such an approach can also account for the paradoxical character of this idea, for example: there has not been a significant reduction in the size of the state since the 1970s; that the scope of state intervention has been increased in 
many areas; and that there has been an increasing use of authoritarian and coercive processes in welfare and other policies (Cahill, 2012, p.115).

\section{Critiquing the foregrounding of neoliberal ideology}

At the start of this paper we made the observation that scholars are divided about the value of neoliberalism as an explanation of political and economic trajectories. Though we recognise the analytical value of $\mathrm{NL}$, it is in this section of the paper that we draw attention to three of the broad criticisms that have been made against the concept of neoliberalism in its entirety. We use three headings: excessive abstraction; a reification of ideology; and an idealisation of politics to distinguish the key criticisms.

\section{Excessive abstraction}

The first charge is that explanations that elevate neoliberal ideology as a primary driver of change are often mistakenly abstracted from actual practice. So, example, neoliberalism is used as a shorthand to describe state retrenchment or reducing services but also deployed to characterise an intensification of governance practices that create the conditions for more private sector profit-making. Such explanations of neoliberalism are increasingly promiscuous in their application (Peck, 2013, p.133). Specifically, as Dean (2014) writes its ubiquity has weakened its heuristic value.

Neoliberalism, it might be argued, is a rather overblown notion, which has been used, usually by a certain kind of critic, to characterize everything from a particular brand of free-market political philosophy and a wide variety of innovations in public management to patterns and processes found in and across diverse political spaces and territories around the globe (Dean 2014, p. 150).

A similar observation is made by Edwards et al (2012, p.6), in arguing that neoliberalism as deployed in scholarship conflates processes that are unconnected; it has become a term to describe 'a collection of political ideas, a political movement, a set of policy practices and a way of organizing the capitalist economy'. All forms of politics in the current era can therefore be termed neoliberal and scholars such as Larner (2003), Shaw (2015) and Newman (2012) have cast doubt on the allencompassing features attributed to its application. Shaw, $(2015$, p.457) pays attention to the different articulations of neoliberalism in academic accounts of contemporary politics. For some it is a black box which all can be explained, for others neoliberalism, explains the logic of capitalist development and its pernicious effects. Similarly, Newman (2012) argues that neoliberalism is not reducible to a 'singular and all-encompassing force', and any attempt to portray NL in this way effectively 'squeezes the capacity both for analysis and for agency (p.158).

\section{The reification of ideology}

The claim that neoliberalism privileges (or reifies) ideology comprises the second main criticism of its application. According to this critique, ideas are important but not determining factor in explaining public policies. The focus on neoliberalism as a 
decisive factor in public policy decision-making, it is suggested overlooks other contingencies, for example: the variations in practice, the institutional environment, and the importance of individual actors. The neoliberal explanation for housing policy rests on the assumption that ideas exert a strong influence on policymakers. Much of the research (see Peck, 2010; Mirowski, 2014; Davies, 2016) traces neoliberal influence to the ideas of the Mont Pelerin Society and economists such as Milton Friedman (1962) who it is claimed saw an opportunity in the mid-1970s to offer monetarist based reforms as a remedy to inflation. According to this view, influential economists operated as co-conspirators who managed to establish a hegemony of neoliberal values on contemporary politics with writers such as Mirowski (2014) and Slater (2012) suggesting an elite group sought to intentionally manufacture doubt and ignorance amongst the wider population.

We acknowledge the studies that have established that, initially at least, neoliberalism was a deliberate strategy designed to impose market disciplines across vast areas of social life but would not wish to overstate the claim that neoliberal ideology has such a direct and singular influence on policy making (see Vengopal 2015 and Dunn 2017). As Dean (2014, p.153) recognises, neoliberalism is multilayered, takes different forms and cannot be reduced to a coherent philosophy and Gamble (2013, p. 56) argues that 'there is a strong tendency to exaggerate the unity and coherence of neoliberalism ... and its diversity must be acknowledged'. Its roots lie in precise intellectual circumstances and therefore it is mistaken to assume a simple causal connection between ideology and public policy outcomes. Cahill (2013, p.71) for example, provides a critique of the 'ideas centred narrative' about neoliberalism, drawing upon research undertaken in Australia; he claims that while conservative based think tanks have exercised an influence on policymaking this relationship is often over stated and difficult to demonstrate. Whilst neoliberal explanations are, in the main, relied upon by housing scholars, writers in disciplines such as geography and sociology have questioned the very basis of neoliberalism as a driver of policy. Hence, in Barnett's (2005) view, those who source government policy direction to NL misunderstand the practices and machinations of government. Much of the NL analysis is presented as a coherent or hegemonic political strategy to restructure welfare and housing policy in ways that favour corporate interests. Such a view, Barnett writes, rests on:

two related propositions: firstly, that political dominance is exercised by the formation of coalitions amongst different interests; and secondly, that the primary medium for suturing together such formations is a set of coherent ideas and images about the world (Barnett, 2005, p. 8).

Neoliberal influences on practices are enacted in different ways but are viewed mistakenly as varieties of a single genus. It would be better, Barnett (2010) suggests, if researchers attend to the actual political practices rather than tracing ideological causation and effects. NL explanations thus offer a compelling moral narrative but 'remain chronically constricted in their capacity to reflect seriously on questions of institutional design, political organisation and economic coordination' (Barnett 2010, p. 271). In similar vein, Jessop (2002), Larner (2003) and more recently Murie (2018) view neoliberalism as just one of the assorted influences that have a bearing on practice. In the context of housing policy in England, Murie (2018, p. 495) argues that 'labelling complex and uneven processes with a catch-all term 
such as 'neoliberalisation' risks being a substitute for explanations of whether and why institutions adopted similar or different strategies and whether their responses reflected various pragmatic considerations'.

So, the designation of the existence of a coherent neoliberal project lends weight then to the notion that there are a cohesive group of actors operating in unison and able to exert enormous influence. This view of the coherence of neoliberalism is apparent in much of cultural studies informed research undertaken in the 1980s and 1990s that centred on the influence of Thatcher and her ideas (see Gamble 1994). Individual politicians such as Thatcher had a considerable impact on Westminster politics, but the reception of the OECD and Western governments to monetarism and neoliberalism were equally the result of broader factors, including technological changes that altered economic production and a combination of rising unemployment and inflation in the 1970s (see Crouch 2011, p.17). Taking aim at accounts that foreground neoliberalism to explain the political objectives pursued by Margaret Thatcher, Marsh (1995) argues that whilst ideology and economic factors were important, the actions of policymakers were often more significant. As he writes

The overall shape of the policies and, even more crucially, the detailed provisions, were strongly affected by strategic political judgements taken by politicians; most of them short-term and concerned with the electoral consequences of actions. The Thatcher Cabinets were also responding to political events, like the 'Winter of Discontent', over which they had no control. 'New Right' ideology played a role, but it was hardly the driving force behind policy (Marsh 1995, p. 595).

In making the case for scholars to consider other factors that shape policy, Marsh stresses the importance of contingency rather than direct ideological determination, acknowledging the recursive duality that links structure and agency and the need to attend to case-by-case examples. Certainly, while Thatcher is credited by her supporters, for extolling the virtues of individualism, many of ideas were already in wide circulation through the 1960s and 1970s and therefore not of her creation.

\section{The idealisation of politics}

A third observation, evident within some of the extant literature on neoliberal ideology is the tendency to critique current policy shortfalls against an idealised and unobtainable version of what politics should be like - so any actual form of existing politics inevitably falls short and hence is subject to critique ${ }^{1}$. Neoliberalism becomes in effect a pejorative term that is applied to all that we do not like or approve of. The limitation of these ideational interpretations of $\mathrm{NL}$ is that they tend to disregard other practices which also shape policy outcomes (see Healey 2006 and Raco 2013). We would agree with Brown's (2015, p.30) portrayal of NL 'as an order of normative reason that, when it becomes ascendant, takes shape as a governing rationality extending a specific formulation of economic values, practices and metrics to every dimension of human life'. However we would caution against any portrayal that seems to dispense with empirical analysis and support Raco's (2003, p. 77) call for a

\footnotetext{
${ }^{1}$ We are grateful to $x x x x x x x x x$ for making these two points in private correspondence.
} 
'reorientation of methodological focus towards the empirical practices of government'.

\section{Entrepreneurial governmentality in the English housing association sector}

Our discussion thus far has been deliberately wide ranging but in this third section we look at a housing context, to illustrate the ways in which neoliberalism might be framed to better explain contemporary developments. Specifically, we focus on the activities of English housing associations to explore the contradictory processes evident in actually existing neoliberalism - what Dardot and Laval (2013, p. 303) have termed 'entrepreneurial governmentality' to describe how values such as commodification, competition and commercialism have been established across welfare bureaucracies, become embedded in organisational behaviours and influenced individual subjectivities.

Dardot and Laval (2013, p.4) argue that 'neoliberalism, far from being an ideology or economic policy, is firstly and fundamentally a rationality and as such tends to structure and organize not only the action of rulers, but also the conduct of the ruled'. Therefore, the underlying rationality is the 'generalization of competition as a behavioural norm and of the enterprise as a model of subjectivation' (p.4). Like Foucault, they emphasise that neoliberalism does not rely solely on disciplinary power to exert influence but through self-government 'to produce a certain type of relationship to the self' (p.5). However, Dardot and Laval advance a more qualified and analytical account than Foucault, whose discussions on neoliberalism did not place as much significance on differences between classical forms of liberalism and neoliberalism. Foucault instead emphasised the enduring role of the ideational 'freemarket' to explain its political reach and penetration. In contrast, Dardot and Laval attend more to the fissures and malleability of neoliberalism showing how individual subjects are required to engage in conduct that requires their adherence to selfimprovement and the principles of competition (see Leonardi (2014) for an extended discussion).

Dispensing with arguments there is a unidirectional relationship whereby the market imposes its influence on the state Dardot and Laval contend that the market/state dichotomy is one of the main obstacles to accurately characterising neoliberalism. Instead, states themselves have universalised and introduced the ethos of competition across the economy, society and government itself. Neoliberalism is thus a deliberate and conjoined set of policies that aim to alter social and economic relations. Dardot and Laval's analysis therefore provides another point of difference with those Foucauldian accounts that portray neoliberalism as a political rather than an economic rationality. According to Dardot and Laval's analysis, neoliberalism should be viewed as a human activity in which actors are entangled in practices across political and economic domains. It is this practical entanglement across economic and political terrains that explains the contradictions and fissures 
within neoliberal practices. As they write '[Neoliberalism is] traversed by tensions and divisions which will later turn into open discussions to the ideological moral, political or even scientific terrains (Dardot and Laval 2013:34).

\section{Methods}

The data used in the next section is drawn from a wider study (conducted by one of the authors) analysing the management of change in the English housing association sector. The study included 20 in-depth, semi-structured interviews with residents $(n=6)$ as well as senior $(n=7)$ and middle managers $(n=7)$ working in housing associations in England (mainly but not exclusively situated in the London area). The empirical data was collected between 2016 and 2017 and the interviews were used to identify how changes to the sector have affected approaches to governance, how they have impacted on organisational values and how everyday practices in the sector have been transformed. Data was analysed thematically to determine key themes and emerging processes as part of a broader analysis of the changing governance of housing. The London area was chosen as it forms the base for the most active, developing housing associations and highlights specific tensions resulting from high land values, a shortage of supply, high levels of unaffordability and inequality and a lack of opportunities for new development (Edwards, 2016). The pressures between entrepreneurialism and collectivism are therefore placed in particularly sharp focus within such an environment. Whilst London may represent a stark contrast with other geographical areas, it does feature some of the most pronounced challenges facing housing organisations working within large urban areas.

We consider housing associations as an appropriate example to develop our claims, for three main reasons. First, because they operate within a sector that has experienced significant transformation under the conditions of neoliberalism. Second, as 'hybrid' institutions (Mullins, Czischke and van Bortel, 2012) housing associations encapsulate the tensions inherent within an environment encompassing public, private and voluntary sector institutional forms. The third reason for analysing this sector is to explore the view that contemporary challenges faced by housing associations are qualitatively distinct from earlier periods. As one chief executive explained:

I think we are at a genuine historical moment in post-war housing history.... there is a crisis of affordability and there is a massive generational issue that characterizes this crisis as quite different from previous cycles. The other big difference is that there isn't a willingness from government to make big interventions in housing supply. They have made significant amounts available for shared ownership but the fact that this is the first government in post war British history to provide no funding at all (for the remainder of this parliament) for sub-market, rental general needs housing (Interview, 11/5/16).

If housing associations are at a genuine historical moment, then how have they responded to these contemporary pressures? As we argue 'entrepreneurial 
governmentality' can be observed across three areas: the changing governance of housing; the values and ethos of the sector and the impact of everyday social practices. We consider each in turn.

\section{Commercialism and the changing governance of housing}

Housing associations from the 1990s, as Murie (2018, p. 491) observed 'came under increased pressure to diversify and generate funds through sales of vacant older properties, building for sale, providing affordable housing with rents well above social housing levels and building for market renting'. As housing associations have assumed a position as the main providers of affordable housing (in the absence of local authorities) there has been increasing attention to their role in changing the governance of housing policy. These changes have been reflected in a number of key areas, including: a professionalisation of board membership (Marsh, 2018); new approaches to organisational strategy and performance; involvement in joint ventures, mergers and acquisitions; diversification into private markets, including construction for and an increased reliance on bond finance, working with credit agencies and private equity firms. There is consequently much greater financial complexity and sophistication across the sector (Marsh, 2018, p. 13).

Mullins (2014) has shown that steer towards corporate governance involve a far greater focus on risk management and mitigation, creating difficulties in involving resident representatives at Board level despite the rhetorical commitment to localism and resident involvement (see also Bradley, 2011). Billis (2010) and Mullins, Czischke and van Bortel (2012) use the term 'hybridity' to characterise how housing associations operate in a sphere between state, market, and civil society that require a 'balancing act' (Blessing, 2012, p.205) to reconcile often incompatible sets of rules, for example to provide local accountability; to access private finance; to reassure regulators and to engage with residents. Governance arrangements consequently reflected commercial sector imperatives and (as one chief executive explained) required a radical change of approach involving, corporate finance and a guarantee of significant revenue streams. Within the English context housing associations therefore:

will generate receipts from market sale and other commercial activities to fund their core affordable housing product, with little or no government support. That does mark a huge change but to be able to do that effectively you really do need scale, you need a massive balance sheet in order to lever those assets and to have the right risk profile to borrow the level of private finance that's required to deliver these large programmes (Interview, 11/5/16).

Following the 2008 GFC, and subsequent government strategy of austerity, housing associations were forced to become increasingly reliant on entrepreneurial finance to fund their activities (Manzi and Morrison, 2018). Increasingly disposed towards a commercial ethos, typified by complex governance structures, involving diverse products and using sophisticated treasury management techniques housing associations prioritised asset management strategies, often involving sale of high value stock (Morrison, 2016) and what one manager described as 'a massive wave of consolidation in the sector' (Interview, 11/5/16) involving a significant number of 
high-profile organisational mergers. The appeal of housing association mergers was accelerated by the government proposal in 2015 to extend the Right to Buy (occupied rental properties) to housing association tenants - a policy intended to be financed by the sale of high-value council property.

At the level of corporate governance, the pressures of entrepreneurialism have strongly influenced approached to the recruitment of board members. Whereas board membership historically involved individuals selected for their housing and social welfare expertise, a background in community working or local-level activism, the complexity of housing association activities inevitably favoured candidates with significant financial and legal expertise. In the words of one Chief Executive: 'Board members will... have to be incredibly financially astute...[involving] property development experience, very high level, senior positions in order to run the organisation' (Interview, 7/6/16).

\section{Commodification in the values and ethos of housing associations}

A second key area where housing associations have been affected by entrepreneurism involve questions about the values and purposes of the sector. As mentioned above, moves towards hybridity involve a delicate balancing act based on the increasing financialisation of the sector - involving extensive reliance on private finance and cross-subsidy (from market renting and property sales). This again raises questions about a role for resident groups in an era dominated by concerns about value for money and the viability of development schemes. As associations are compelled to consider the disposal of high value stock and to pursue development in low cost areas this raises concerns about increasing spatial segregation (Marsh, 2018, p.14). Although Marsh also warns that there has been a tendency to focus on the activities of the large London housing associations; the socalled G15 group of large London HAs it seems clear that, influenced by the literature on institutional logics, housing associations have become subject to the influence of the 'remorseless and transactional logic of finance' (Marsh, 2018, p.16). The challenges of the resultant need to balance competing demands creates dissonance and contradictions, as evident in the comments of a senior manager working for a London housing association. As he explained: 'We are constantly wrestling to maintain a social purpose - it's something we talk a great deal about and we have to accept changes that were never there before' (Interview, 11/6/16).

The pressure on housing associations to operate in ways that were similar to commercial businesses was identified as troubling. Consider the views of another Chief Executive, who explained the importance of retaining the social values of the organisation. As he explained: "We have to keep reminding ourselves of our values. When people say 'you're a landlord' we say 'no, we are a social landlord" (Interview, 18/3/17). In a response to overt financialization and the charge that housing associations are becoming increasingly commercial, some associations have responded by portraying themselves as local 'community anchor organisations' who perform an important role in facilitating 'inclusive growth' (RSA, 2017). However, as McKee (2015) has suggested, this 'revival of the local' should not necessarily be viewed at face value but instead understood as a technology of governance enacted to manage 'the crisis within the neoliberal project by valorising policy solutions at the local scale' (1078). 


\section{Competition and everyday social practice}

The third area of housing association activity we identify is the impact of everyday social practices. In broader terms, housing associations have become required by the government to extend welfare conditions on tenants through the use of sanctions and penalties (Watts and Fitzpatrick, 2018). These sanctions are informed by assumptions about the supposedly perverse incentives created through the provision of social housing. An influential report published by a centre-right commentator (Morton, 2010) characterised social housing in the following way:

Current social housing policies are driving unaffordable levels of welfare reliance and increasing poverty for social tenants - evidenced by an 'unexplainable gap' between social tenants' much lower rates of employment when compared with similar individuals outside the sector. This is caused by the appalling incentives that social tenants face (Morton, 2010, p. 5).

We can see evidence of the moralization of conduct in the ways that housing association staff evoke entrepreneurial discourses to cajole residents to take up employment and to become 'better' neighbours. Policies and practices are instigated to implement good neighbour agreements, acceptable behaviour contracts and to reduce security of tenure through 'flexible' or 'fixed term' tenancies (Watts and Fitzpatrick, 2018). In the words of Boughton (2018) 'we now have a state which, while it once promised its citizens security, seems to be offering and valuing insecurity (268, emphasis in original). The imposition of regulations on tenants was discussed by a chief executive of a housing association, who described its implementation as 'training in having difficult conversations' (Interview, 18/3/18). These 'difficult' conversations involved refusing requests from residents, charging for non-essential repairs, promoting employment and emphasising the need for neighbourliness (see Wacquant (2012) for a detailed examination of the disciplinary function of modern welfare institutions).

A changing approach to practice was also strongly evident in regeneration initiatives; where the notion of regeneration was presented unproblematically to describe the renewal of public housing estates, whereas the forms in which schemes have been delivered have been widely critiqued. So for example, Hodkinson, Watt and Mooney (2013, p.3 view it as 'part of a wider neoliberalising agenda, an agenda that is driven by a particular class project' (Hodkinson, Watt and Mooney, 2013, p.3.) It is claimed that both regeneration and mixed income housing serve as a disguise for further commodification that eventuates in displacement, eviction and alienation of long standing tenants (Hearne, 2011; Slater, 2012; Watt, 2016; Watt and Minton, 2016, Madden and Marcuse 2016).

Aside from these broad categorisations of regeneration it is helpful to consider in the specific conditions, processes and outcomes of specific schemes. For example, the redevelopment of the Heygate estate (in the London Borough of Southwark) resulted in an almost complete absence of social housing - as private developers imposed their demands in negotiations that eventuated in the local authority granting huge concessions in its eagerness for the project to be completed (Lees and Ferrari, 2016). 
It should be acknowledged that some authors are more sanguine about contemporary regeneration for example, Lupton and Tunstall (2008) view mixed community policies as provoking a 'social justice dilemma', which on the one hand involved a progressive objective to limit social segregation, encourage social mobility and facilitate social integration. On the other hand, the form of many of these strategies (based on an assumption about the behaviour of disadvantaged groups) resulted in less desirable outcomes (often involving residential displacement and significant rent gaps). Lupton and Tunstall's point is to understand both the potential desirable objectives, but practical barriers to their realisation. Here it is important to acknowledge what Flint (2018) has termed the 'dilemmas of practice' wherein practitioners work within severe constraints and attempt to mitigate rather than exacerbate the consequences of neoliberal policy. As one senior manager commented the constraints of neoliberalism exacerbated the need for more (rather than less) supportive approach to residents:

If anything, these things become even more important as communities struggle with welfare cuts and poverty. We want to help unlock the potential of our residents...I think its short-sighted to say that we are just going to hunker down to the basic landlord function of collecting the rent and carrying out emergency repairs. It's got to be more than that. We are resolute in not wanting to go down that route (Interview, 11/5/16).

Such comments highlight the contradictory processes at work in the neoliberal project, involving both withdrawal and extension of state practices as well as the scope for endorsement and resistance to entrepreneurial forms of governmentality.

\section{Conclusion}

At the start of the paper, we suggested that it is important to consider the divergent ways that neoliberalism has been conceptualised and deployed in the field of housing studies. In identifying the competing interpretations neoliberalism we argue that the governmentality approach has the most utility for explaining contemporary housing policy because of its focus on the actually existing aspects of neoliberalism. Following Dardot and Laval (2013), neoliberalism can therefore be seen both as a set of ideas and a political project that has established entrepreneurialism and competition across government, the economy and social life as a whole.

Dardot and Laval (2013), in contrast to earlier Foucauldian accounts, make the explicit case for social science researchers to conjoin the ideology of neoliberalism alongside the transversal features of contemporary practice. In this respect, their arguments concur with Ryan's (2016, p.91) claim that an 'understanding of neoliberalism cannot focus on just ideas or practice, rather on the diverse ways these two spheres intersect and interact - this interplay must become incorporated into the established 'actually existing' framework'. An attention to ideas and practice makes it possible to avoid some of the problems that can arise when deploying neoliberalism as an explanatory framework - for example in overstating its 
ideational features and neglecting the variations arising from actions pursued by individuals and organisations. The discussion of English housing associations provided an example of how neoliberalism is both a set of ideas and a mode of governmentality. In exploring some of the ideational and practical pressures facing these organisations, we considered the governance processes required to straddle welfare and commercial imperatives; the pressures involved in defining core organisational values and finally the everyday social practices undertaken by housing associations (in areas such as regeneration). This analysis therefore highlights the contradictions and dissonance involved in housing association activities and extends existing knowledge of neoliberalism and other transnational processes considered in housing scholarship (see for example Mullins, Czischke and van Bortel, 2012; Blessing, 2016), by situating the discussion within a broader theoretical analysis.

In respect of practice, the example of English housing associations not only reveals, in stark terms, the institutional responses that have been in evidence from the 1990s to neoliberal forms of governmentality but also the difficult choices that confront staff as they seek to reconcile entrepreneurial values with more traditional welfare concerns. At an ideational level, the example supports Dardot and Laval's (2013 p. 262) observation that under the conditions of entrepreneurial governmentality, 'individuals are rendered more capable of tolerating the new conditions created for them - and this even though they help to make the conditions increasingly harsh and abiding through their own conduct'.

As for future research, we suggest that the proposed framework (governance, values and practices) sketched out in this paper can be adapted to explore housing issues that also feature in other nation states where the impost of entrepreneurialism, in the form privatisation, competition and choice are also evident. The task for housing researchers who wish to make use of the concept of neoliberalism is to study and analyse its economic components (such as marketization, commodification and financialization), its moralizing features (in reinforcing an entrepreneurial rationality) and as well as its broader and variegated socio-political effects.

\section{References}

Aalbers, M. (2016) The Financialization of Housing: A Political Economy Approach London: Routledge.

Barnett, C. (2005) 'Critical review: the consolations of neoliberalism', Geoforum 36, pp. 7-12. https://doi.org/10.1016/j.geoforum.2004.08.006

Barnett, C. (2010) 'Publics and markets: what's wrong with neoliberalism?' In: Smith S., Pain, R., Marston, S. and Jones III, J.P. (eds.) The Sage Handbook of Social Geographies, London: Sage, pp. 269-296. 
Bevir, M. (2012) 'Governance and governmentality after neoliberalism', Policy and Politics, 39 (4): 457-71. DOI:10.1332/030557310X550141

Billis, D. (2010) 'From welfare bureaucracies to welfare hybrids'. In D. Billis (Ed). Hybrid Organisations and the Third Sector: Challenges for Practice, Theory and Policy. Basingstoke: Palgrave Macmillan, pp.3-24.

Blessing, A. (2012) 'Magical or monstrous? Hybridity in social housing governance', Housing Studies, 27 (2), pp.189-207. DOI: 10.1080/02673037.2012.649469

Blessing, A. (2016) 'Repackaging the poor? Conceptualising neoliberal reforms of social rental housing', Housing Studies, 31(2), pp.149-172, DOI: 10.1080/02673037.2015.1070799

Blyth, M. (2013) Austerity: The History of a Dangerous Idea, New York: Oxford University Press.

Boas, T. and Gans-Morse, J. (2009) 'Neoliberalism: from new liberal philosophy to anti-liberal slogan', Studies in Comparative International Development 44, 2, pp.13761. https://link.springer.com/content/pdf/10.1007\%2Fs12116-009-9040-5.pdf

Boughton, J. (2018) Municipal Dreams: The Rise and Fall of Council Housing London: Verso.

Bradley, Q. (2011) 'Trouble at the top? The construction of tenant identity in the governance of social housing organisations, Housing, Theory and Society, 28, 1, pp. 19-38. DOI: 10.1080/14036096.2010.496255

Cahill, D. (2012) 'The embedded neoliberal economy', in D. Cahill, L. Edwards and F. Stilwell (eds.) Neoliberalism: Beyond the Free Market Cheltenham: Edward Elgar pp.110-127.

Cahill, D. (2013) 'Ideas-centred explanations of the rise of neoliberalism: a critique' Australian Journal of Political Science 48 (1), pp.71-84.

DOI: $10.1080 / 10361146.2012 .761174$

Crouch, C. (2008) 'What will follow the demise of privatised Keynesianism?', The Political Quarterly, 79: 476-87. DOI: 10.1111/j.1467-923X.2008.00970.x

Crouch, C. (2011) The Strange Non-Death of Neoliberalism London: Polity.

Dardot, P. and Laval, C. (2013) The New Way of the World: On Neoliberal Society London: Verso.

Davies, J. (2011) Challenging Governance Theory: From Networks to Hegemony Bristol: Policy Press.

Davies, W. (2014) The Limits of Neoliberalism: Authority, Sovereignty and the Logic of Competition London: Sage. 
Dean, M. (2014) 'Rethinking neoliberalism', Journal of Sociology, 50, 2, pp.150-63.

DOI: $10.1177 / 1440783312442256$

Duménil, G., \& Lévy, D. (2004). Capital Resurgent: Roots of the Neoliberal

Revolution. Cambridge MA: Harvard University Press.

Dunn, B. (2017) 'Against neoliberalism as a concept' Capital and Class 41 (3) pp.435 -454. DOI: 10.1177/0309816816678583

Edwards, M. (2016) 'The housing crisis and London', City, 20, (2), pp.222-237.

DOI: $10.1080 / 13604813.2016 .1145947$

Edwards, L., Cahill, D. and Stilwell, F. (2012) 'Introduction: understanding neoliberalism beyond the free market' in D. Cahill, L. Edwards and F. Stilwell (eds) Neoliberalism: Beyond the Free Market Cheltenham: Edward Elgar, pp.1-14.

Fields, D. (2017) 'Unwilling subjects of financialization' International Journal of Urban and Regional Research 41 (4), pp. 588-603. DOI: 10.1111/1468-2427.12519

Flint, J. (2010) 'Housing and ethopolitics: constructing identities of active consumption and responsible community', Economy and Society, 32, 3, pp.611-629. DOI: $10.1080 / 0308514032000107628$

Flint, J. (2018) 'Encounters with the centaur state: Advanced urban marginality and the practices and ethics of welfare sanctions regimes', Urban Studies, pp.1-17. DOI: http://dx.doi.org/10.1177/0042098017750070

Forrest, R. and Hirayama, Y. (2015) 'The financialisation of the social project: embedded liberalism, neoliberalism and homeownership' Urban Studies, 52 (2)233244. DOI: $10.1177 / 0042098014528394$

Foucault, M. (2008) The Birth of Biopolitics: Lectures at the College de France,19781979, ed. M. Snellart, trans. G. Burchell. London: Palgrave Macmillan.

Friedman, M. (1962) Capitalism and Freedom Chicago, II.: University of Chicago Press.

Gamble, A (1994) The Free Economy and the Strong State (2 ${ }^{\text {nd }}$ edition), Basingstoke: Palgrave.

Gamble, A. (2013) 'Economic libertarianism', in Resilient Liberalism in Europe's Political Economy, eds. V. Schmidt \& M. Thatcher, Cambridge: Cambridge University Press, pp. 53-76.

Glynn, S. (2009) 'Introduction' in S. Glynn (ed.) Where the Other Half Lives London: Pluto Press, pp.1-8.

Hall, S. (1988) The Hard Road to Renewal, London: Verso.

Harvey, D. (2005) A Brief History of Neoliberalism Oxford: Oxford University Press. 
Hayek, F. (1944) The Road to Serfdom London: Routledge.

Healey, P. (2006) 'Transforming governance: challenges of institutional adaptation and a new politics of space' European Planning Studies Vol. 14 No. 3 pp299-320. DOI: $10.1080 / 09654310500420792$

Hearne, R. (2011) Public Private Partnerships in Ireland: Failed Experiment or the Way Forward for the State? Manchester: Manchester University Press.

Hilgers, M (2010) 'The three anthropological approaches to neoliberalism' International Social Science Journal 61 (202), pp. 351-364. DOI: 10.1111/j.14682451.2011.01776.x

Hodkinson, S. (2011) 'Housing regeneration and the private finance initiative in England: unstitching the neoliberal urban straitjacket' Antipode 43 (2) 358-383. DOI: 10.1111/j.1467-8330.2010.00819.x

Hodkinson, S., Watt, P. and Mooney, G. (2013) 'Neoliberal housing policy - time for a critical reappraisal' Critical Social Policy, 33, 1, pp. 3-16.

DOI: $10.1177 / 0261018312457862$

Holbrow, M. (2015) Language and Neoliberalism, London: Routledge.

Jessop, B. (2002) 'Liberalism, neo-liberalism and urban governance: a state theoretical perspective' Antipode 34, pp. 452-472. DOI: 10.1111/1467-8330.00250

Klein, N, (2007) The Shock Doctrine: The Rise of Disaster Capitalism New York: Picado.

Larner, W. (2003) 'Neoliberalism?' Environment and Planning D, 12, pp. 509-12. DOI: $10.1068 / \mathrm{d} 2105 \mathrm{ed}$

Lazzarato, M. (2012) The Making of the Indebted Man, Amsterdam: Semiotext(e)

Lees. L. and Ferreri, M. (2016) 'Resisting gentrification on its final frontiers: learning from the Heygate estate in London' (1974-2013), Cities, 57, pp. 14-24.

DOI: 10.1016/j.cities.2015.12.005.

Leonardi, E. (2014) 'Review of Dardot \& Laval's The New Way of the World: on Neoliberal Society' Theory, Culture and Society (Open Access) https://www.theoryculturesociety.org/review-of-dardot-lavals-the-new-way-of-theworld-on-neoliberal-society/ (accessed 30 th April 2019).

Lupton, R. and Tunstall, R. (2008) 'Neighbourhood regeneration through mixed communities: a "social justice dilemma", Journal of Education Policy, 23, (2), pp. 105-117. DOI: $10.1080 / 02680930701853013$

McKee, K. (2009) 'Post-Foucauldian governmentality: what does it offer critical social policy analysis?' Critical Social Policy, 35, 1: 465-86.

DOI: $10.1177 / 0261018309105180$ 
McKee, K., (2015) 'Community anchor housing associations: illuminating the contested nature of neoliberal governing practices at the local scale', Environment and Planning C, 33: pp. 1076-1091. DOI: 10.1177/0263774X15605941

Madden, D. and Marcuse, P. (2016) In Defense of Housing London: Verso.

Manzi, T. and Morrison, N. (2018) 'Risk, commercialism and social purpose: Repositioning the English social housing sector', Urban Studies, 55, 9, pp.1-18. DOI: $10.1177 / 0042098017700792$

Marsh, A. (2018) Social Housing Governance: An Overview of the Issues and Evidence Glasgow: University of Glasgow, UK Collaborative Centre for Housing Evidence.

Marsh, D. (1995) 'Explaining Thatcherite policies: beyond uni-dimensional explanation', Political Studies, 43, 4, pp. 595-613.

Mirowski, P. (2014) Never let a Serious Crisis go to Waste: How Neoliberalism Survived the Financial Meltdown London: Verso.

Mirowski, P. and Plehwe, D. (eds.) (2009) The Road from Mont Pelerin: The Making of a Neoliberal Thought Collective Cambridge, MA: Harvard University Press.

Morrison, N. (2016) 'Selling the family silver? Institutional entrepreneurship and asset disposal in the English housing association sector', Urban Studies, 54 (12), pp. 2856-2873. DOI: 10.1177/0042098016653874

Morton, A. (2010) Making Housing Affordable: A New Vision for Housing Policy London: Policy Exchange.

Mullins, D. (2014) 'The evolution of corporate governance structures and relationships in English housing associations', in C. Cornforth and W.A. Brown (eds.) Nonprofit Governance: Innovative Perspectives and Approaches, Abingdon: Routledge, pp.210-228.

Mullins, D., Czischke, D. and van Bortel, G. (2012) 'Exploring the meaning of hybridity and social enterprise in housing organisations' Housing Studies, 27 (4) 405-417. DOI: 10.1080/02673037.2012.689171

Murie, A. (2018) 'Shrinking the state in housing; challenges, transitions and ambiguities' Cambridge Journal of Regions, Economy and Society, 11, pp. 485-501, https://doi.org/10.1093/cjres/rsy024

Newman, J. (2012) Working the Spaces of Power: Activism, Neoliberalism and Gendered Labour London: Bloomsbury

Peck, J. (2010) Constructions of Neoliberal Reason Oxford: Oxford University Press. 
Peck, J. (2013) 'Explaining (with) neoliberalism', Territory, Politics, Governance, 1, 2, pp.132-157.

Peck, J., Theodore, N. and Brenner, N. (2009) 'Post neoliberalism and its malcontents', Antipode, 41, pp. 94-116. DOI: 10.1111/j.1467-8330.2009.00718

Peck, J. and Tickell A. (2002) 'Neoliberalizing space' Antipode No.32 pp. 380-404. DOI: $10.1111 / 1467-8330.00247$

Raco, M. (2003) 'Governmentality, subject-building and the discourse and practices of devolution in the UK', Transactions of the Institute of British Geographers 28, 7595. DOI: 10.1111/1475-5661.00078

Raco, M. (2013) State-led Privatisation and the Demise of the Democratic State, Aldershot: Ashgate.

Rolnik, R. (2013) 'Late neoliberalism: the financialization of homeownership and housing rights', International Journal of Urban and Regional Research, 37 (3) 10581066. DOI: 10.1111/1468-2427.12062

Rose, N. (2000) 'Community, citizenship and the Third Way', American Behavioural Scientist, 43:1395-1411.https://doi.org/10.1177\%2F00027640021955955

Royal Society of the Arts (RSA) (2017) Five Ways that Housing Associations Underpin Inclusive Growth London: RSA

Ryan, M. (2016) 'Contesting actually existing neoliberalism', The Journal of Australian Political Economy, 76: 79-102, https://search.informit.com.au/documentSummary;dn=790843329061852;res=IELBu $\mathrm{s}$

Self, P. (2000) Rolling Back the Market: Economic Dogma and Political Choice, London: Macmillan.

Shaw, R. (2015) ' 'Alive after five': Constructing the neoliberal night in Newcastle upon Tyne', Urban Studies, 52(3) February, 456-470, DOI:

$10.1177 / 0042098013504008$

Slater, T. (2012) 'The myth of broken Britain: welfare reform and the production of ignorance', Antipode, 46, 4, pp. 948-969. DOI: 10.1111/anti.12002

Swyngedouw, E. (2005) 'Governance, innovation and the citizen: the Janus face of governance-beyond-the state', Urban Studies, 42(11), pp. 1991-2006.

DOI: $10.1080 / 00420980500279869$

Vengopal, R. (2015) 'Neoliberalism as a concept' Economy and Society 44 (2), pp.. 165-187. DOI: 10.1080/03085147.2015.1013356

Wacquant, L. (2012) 'Three steps to a historical anthropology of actually existing neoliberalism', Social Anthropology/Anthropologie Sociale 20 (1), pp. 66-79.

DOI: 10.1111/j.1469-8676.2011.00189.x 
Watt, P. (2016) 'A nomadic war machine in the metropolis: En/countering London's $21^{\text {st }}$ century housing crisis with Focus E15', City, vol.22, no.2, pp.297-320.

DOI: $10.1080 / 13604813.2016 .1153919$

Watt, P. and Minton, A. (2016) 'London's housing crisis and its activisms' City 20 (2), pp. 204-221. DOI: 10.1080/13604813.2016.1151707

Watts, B. and Fitzpatrick, S. (2018) Welfare Conditionality London: Routledge. 